\section{Dr. Luis Alberto Pacheco Rivas (1958-2014)}

$\mathrm{T}$ odo hombre es a su época y a sus vivencias, sin embargo, al momento de ponderar su valer, lo que cuenta son las virtudes morales que ha practicado; los valores y los principios que ha practicado y le han movido. Sin miedo y sin egoísmos, marcado desde la juventud, por la formación familiar y la Universidad de Concepción: fue dotado de una moralidad y ética superior, de la fuerza y del valor para defender sus ideas, de los sentimientos de filantropía, justicia social y amor por la democracia, a la verdad y el respeto de las conciencias.

Trabajó como Médico General de Zona en Purén, tras lo cual se formó como neurólogo en la Universidad de Chile, sede Oriente, en el Hospital del Salvador de Santiago.

Resulta imposible detallar en un somero esbozo, su personalidad tan dinámica y creadora, toda su obra fruto de sus estudios, la formación médica como neurólogo, el trabajo asistencial desarrollado preferentemente en un servicio público, el reconocimiento y respeto de sus colegas, el entusiasmo como académico. Con sus colegas y amigos compartió y contribuyó al desarrollo de la especialidad en Temuco, en una vida dedicada al trabajo asistencial en el Hospital Regional de Temuco "Hernán Henríquez Aravena" y en la Universidad de la Frontera. Ocupó el cargo de Jefe de Servicio y por años fue también activo académico docente, reconocido por generaciones de alumnos, hoy médicos, que enriquecieron su formación con sus conocimientos y ejemplo de su inmaculado y recto proceder y su siempre sereno, afable y generoso consejo.

A la sapiencia y las virtudes, se sumaron sus sobresalientes condiciones personales de hombre culto y de clara iniciativa intelectual. No fue aspirante a honores, medallas o prebendas.

Como padre de familia, consideraba que no bastaba con la instrucción y competencias profesionales, sino que era indispensable ser una buena persona.

Hizo su magistral trabajo en cumplimiento del llamado irrenunciable de sus vocaciones. Le interesaba la satisfacción del deber cumplido, la cosa bien hecha y sólo esperaba la recompensa generosa de la sonrisa, la gratitud y la confianza de quienes fueron sus pacientes, sus alumnos, colegas y amigos.

La acabada conciencia ética de su quehacer, su actuar llano, ponderado y respetuoso, su elevado criterio, su bondad, su personalidad afable y temperamento amistoso, le significarán el permanente reconocimiento y estima de quienes le conocieron y compartieron con él.

Finalmente, puedo decir que consideraba la educación y el trabajo, como fuente de libertad para el hombre, ya que constituyen su medio de superación y de dignificación personal. Estaba muy preocupado por los conflictos sociales y por los problemas de la educación en el Chile de hoy, teniendo siempre la esperanza de que finalmente reinarán la tolerancia y la concordia y que la justicia y la paz social son necesarias para todo progreso.

Dr. Oscar Jiménez L. 